\title{
Ascochyta fabae and A. lentis: Host Specificity, Teleomorphs (Didymella), Hybrid Analysis, and Taxonomic Status
}

\author{
W. J. Kaiser, USDA-ARS, Western Regional Plant Introduction Station, Washington State University, P.O. Box \\ 646402, Pullman 99164-6402; and B.-C. Wang and J. D. Rogers, Department of Plant Pathology, Washington \\ State University, P.O. Box 646430, Pullman 99164-6430
}

\begin{abstract}
Kaiser, W. J., Wang, B.-C., and Rogers, J. D. 1997. Ascochyta fabae and A. lentis: Host specificity, teleomorphs (Didymella), hybrid analysis, and taxonomic status. Plant Dis. 81:809-816.

Isolates of Ascochyta fabae from faba bean (Vicia faba) and A. lentis from lentil (Lens culinaris) collected from different countries were used in this study. The Didymella teleomorph (sexual state) of each fungus was induced to develop and mature on inoculated sterile lentil stems. Both fungi were heterothallic, with two mating types, designated MAT1-1 and MAT1-2. When certain isolates of A. fabae and A. lentis were crossed, hybrid pseudothecia developed. Growth, sporulation, colony appearance, morphology, and pathogenicity of the hybrid progeny frequently differed greatly from the parent isolates. Inoculations with single-ascospore progeny from matings among compatible isolates of $A$. fabae caused disease in faba bean but not in lentil; inoculations with single-ascospore progeny from matings among compatible isolates of A. lentis incited disease in lentil but not in faba bean. Inoculations with single-ascospore progeny from crosses between faba bean and lentil isolates did not induce disease in either host. Asci from crosses between A. fabae and A. lentis mostly contained fewer than eight ascospores that were, on average, larger than those from eight-spored asci. Matings among certain isolates of A. fabae resulted in production of pseudothecia with ascospores considerably larger than is typical for $D$. fabae. Random amplified polymorphic DNA (RAPD) banding patterns of Ascochyta isolates from faba bean and lentil are clearly different, and banding patterns from hybrid progeny from crosses between A. fabae and A. lentis confirmed hybridity. RAPD markers proved useful in supporting identifications of ascospore isolates from faba bean to known Ascochyta species. Dendrogram analysis indicated similarity between the two fungal species was low. The pathogenicity tests, morphological characteristics, and RAPD markers indicate that A. fabae and $A$. lentis represent distinct taxa. D. lentis, with its anamorph, $A$. lentis, is proposed as a new species that is distinct from $D$. fabae, with its anamorph, A. fabae.
\end{abstract}

Additional keywords: Ascochyta blight

Ascochyta blights are important foliar diseases of faba bean (Vicia faba L.) and lentil (Lens culinaris Medik.) in many countries. Disease of faba bean is incited by Ascochyta fabae Speg., whereas disease of lentil is incited by A. lentis Vassilievsky (=A. fabae f. sp. lentis Gossen et al.). Both pathogens are seedborne in their respective

Corresponding author: W. J. Kaiser

E-mail: wjkaiser@wsu.edu

PPNS 0245, Department of Plant Pathology, Washington State University, College of Agriculture and Home Economics, Pullman.

Mention of a trademark or proprietary product is solely to identify materials used and does not constitute a guarantee or warranty of the product by the U.S. Department of Agriculture and does not imply its approval to the exclusion of other products that may also be suitable.

Accepted for publication 7 April 1997.

Publication no. D-1997-0516-04R

This article is in the public domain and not copyrightable. It may be freely reprinted with customary crediting of the source. The American Phytopathological Society, 1997. hosts. A. fabae and A. lentis have been separated primarily based on their pathogenic specialization for faba bean and lentil, respectively (1). Gossen et al. (3) made multivariate comparisons of the morphological and cultural characteristics of $A$. fabae and $A$. lentis and suggested that they represent a morphological continuum. Subsequently, Gossen et al. (2) advocated that A. lentis be synonymized with $A$. fabae and proposed two special forms: A. fabae f. sp. fabae for isolates pathogenic on faba bean and A. fabae f. sp. lentis for isolates pathogenic on lentil. Jellis and Punithalingam (6) discovered Didymella fabae Jellis \& Punith., the teleomorph of $A$. fabae, on overwintered faba bean straw in the United Kingdom. More recently, Didymella sp., the teleomorph of A. lentis, was found on overwintered lentil debris in the Palouse region of eastern Washington and northern Idaho (9). The teleomorphic state may play an important role in (i) generating increased genetic diversity in the pathogen, which could adversely affect resistance breeding programs and chemical control strategies; (ii) producing airborne ascospores that may serve as a primary inoculum; and (iii) aid- ing in survival of the fungus from one growing season to the next on infested crop debris.

The objectives of this study were (i) to examine the pathogenicity of progeny from matings among and between A. fabae and A. lentis; (ii) to observe the morphology of asci and ascospores of these two species and their hybrids; and (iii) to determine whether it is possible to separate these two species based on random amplified polymorphic DNA (RAPD) markers. We also used RAPD assays to determine the geographic distribution of isolates of $A$. fabae with certain morphological characteristics, using worldwide collections. RAPD assays also were performed to examine the relationships of ascospore isolates from faba bean to known Ascochyta spp. and to determine the possibility of using RAPD markers to support identifications.

\section{MATERIALS AND METHODS}

Ascochyta isolates. Isolates of $A$. fabae (43) and A. lentis (341) from different countries were obtained from cooperators or were isolated by W. J. Kaiser from diseased plant tissues. Isolates used in the morphology, pathogenicity, and RAPD studies are listed in Table 1. Two mating types of D. rabiei (Kovachevski) von Arx (anamorph A. rabiei (Pass.) Labrousse), ATCC 76501 and ATCC 76502, a pathogen of chickpea (Cicer arietinum L.), were included to assess the potential of forming hybrids with the former two taxa and to serve as a potential outgroup in molecular studies. Two unidentified ascospore isolates from faba bean from Lebanon (A) and Syria (C) also were included. Plant tissues were surfacedisinfected in $0.25 \% \mathrm{NaOCl}$ for $5 \mathrm{~min}$, dried on paper towels, and placed on $2 \%$ water agar (WA) in 9-cm-diameter plastic petri dishes. Dishes were incubated at 21 to $23^{\circ} \mathrm{C}$ under fluorescent lights (12-h photoperiod, $77 \mu \mathrm{E} \mathrm{m}^{-2} \mathrm{~s}^{-1}$ ). Single spores of all isolates were placed on potato dextrose agar (PDA; Difco Laboratories, Detroit). To induce abundant sporulation, isolates of $A$. fabae were cultured on faba bean seed mealdextrose agar (FDA) (2\% faba bean flour, $2 \%$ dextrose, and $2 \%$ agar in 1 liter of deionized water), isolates of $A$. lentis were cultured on lentil seed meal-dextrose agar (LDA) (2\% lentil flour, 2\% dextrose, and $2 \%$ agar in 1 liter of deionized water), and isolates of $A$. rabiei were cultured on chickpea seed meal-dextrose agar (CDA) $(5 \%$ chickpea flour, $2 \%$ dextrose, and $2 \%$ agar 
in 1 liter of deionized water). Single-ascospore and conidial cultures of the three Ascochyta spp. on PDA, FDA, LDA, and CDA were incubated at 21 to $23^{\circ} \mathrm{C}$ under fluorescent lights (12-h photoperiod) in dishes sealed with Parafilm.

For short-term storage, isolates were maintained on the media at $4^{\circ} \mathrm{C}$ in the dark. For long-term storage, isolates of A. fabae, A. lentis, and A. rabiei were cultured on autoclaved stem pieces of faba bean, lentil, and chickpea, respectively, as follows: 4- to 6$\mathrm{cm}$ dry, sterile stem pieces were submerged in a heavy spore suspension of each isolate for 45 to $60 \mathrm{~min}$ and placed on WA in sealed dishes at 21 to $23^{\circ} \mathrm{C}$ under fluorescent lights (12-h photoperiod) for 2 weeks. The colonized stem pieces were dried for 3 to 5 days at room temperature and stored in sterile plastic Whirl-Pak (Nasco, Ft. Atkinson, WI) bags at $-18^{\circ} \mathrm{C}$.

Table 1. Isolates of Ascochyta fabae, A. lentis, and A. rabiei used in morphological, pathogenicity, and random amplified polymorphic DNA studies

\begin{tabular}{|c|c|c|c|}
\hline $\begin{array}{l}\text { Isolate } \\
\text { number }\end{array}$ & $\begin{array}{c}\text { Isolate } \\
\text { designation }\end{array}$ & $\begin{array}{l}\text { Country } \\
\text { of origin }\end{array}$ & $\begin{array}{l}\text { dark at } 10^{\circ} \mathrm{C} \text { for } 5 \text { weeks. The petri dishes } \\
\text { were not sealed or placed in air-tight con- }\end{array}$ \\
\hline \multicolumn{4}{|l|}{$\overline{\text { A.fabae }}$} \\
\hline 1 & $\mathrm{AF} 3$ & Afghanistan & dried at 21 to $23^{\circ} \mathrm{C}$. To discharge asco- \\
\hline 2 & AF $1(96418)^{\mathrm{a}}$ & Canada & res, stem pieces were placed on a $4-\mathrm{cm}^{2}$ \\
\hline 3 & $\mathrm{AF} 2$ & Canada & WA block attached to the inner surface of a \\
\hline 4 & AF 7 & Canada & petri dish lid that was inverted over the \\
\hline 5 & AF 12 & Canada & bottom dish, which contained WA. Ascospore \\
\hline 6 & AF 13 (38599) & Canada & discharge usually began within 1 to $2 \mathrm{~h}$, and \\
\hline 7 & AF 5 & Germany & germination of ascospores occurred within \\
\hline 8 & AF 6 & Germany & 4 to $7 \mathrm{~h}$ at 21 to $23^{\circ} \mathrm{C}$. \\
\hline 9 & $\begin{array}{l}\text { AF } 4 \text { (96409) } \\
\text { AF } 14\end{array}$ & $\begin{array}{l}\text { Iran } \\
\text { Snain }\end{array}$ & When it was observed that pairings of \\
\hline $\begin{array}{l}10 \\
11\end{array}$ & $\begin{array}{l}\text { AF } 14 \\
\text { AF } 15\end{array}$ & $\begin{array}{l}\text { Spain } \\
\text { Spain }\end{array}$ & compatible isolates were required to devel- \\
\hline 12 & AF 16 & Spain & op fertile pseudothecia, two compatible iso- \\
\hline 13 & AF 17 & Spain & lates of $A$. fabae, $\mathrm{AF} 1$ and $\mathrm{AF} 4$, and \\
\hline 14 & AF 18 & Syria & A. lentis, AL 1 and AL 2, were deposited \\
\hline 15 & AF 19 & Syria & with the American Type Culture Collection \\
\hline 16 & AF 20 & Syria & (ATCC), Rockville, MD, as ATCC 96418 \\
\hline 17 & AF 8 & U.K. & and 96409 and ATCC 96419 and 96420 , \\
\hline 18 & AF 9 & U.K. & respectively. These isolates were selected \\
\hline 19 & AF 10 & U.K. & as testers for mating-type studies with 43 \\
\hline 20 & AF 11 & U.K. & \\
\hline
\end{tabular}

Matings. Hybridization experiments were done to determine whether $A$. fabae and $A$. lentis were homo- or heterothallic. Sterile lentil stem pieces were inoculated with spore suspensions of single isolates alone or mixtures of isolates of each Ascochyta spp. The procedure used to mate isolates was a modification of the blotter technique developed by Trapero-Casas and Kaiser (16) and Wilson and Kaiser (18) for D. rabiei. Conidial suspensions (about $1 \times 10^{6}$ conidia per $\mathrm{ml}$ ) were prepared from single-spore cultures of the A. fabae and A. lentis isolates. Sterile lentil stem pieces (6 to $8 \mathrm{~cm}$ long) were sterilized with propylene oxide (5) and placed in $2.2 \times 17.5-\mathrm{cm}$ test tubes containing $20 \mathrm{ml}$ of a conidial suspension of a single isolate or mixtures of isolates of each fungal species for about $1 \mathrm{~h}$, at which time the liquid was decanted. After draining for 10 to $15 \mathrm{~min}$ in the test tubes, the inoculated stem pieces were placed on 10 layers of filter paper moistened with $15 \mathrm{ml}$ of sterile distilled water in Pyrex petri dishes (10-cm diameter). The dishes were incubated at 21 to $23^{\circ} \mathrm{C}$ for $24 \mathrm{~h}$ and in the dark at $10^{\circ} \mathrm{C}$ for 5 weeks. The petri dishes were not sealed or placed in air-tight conair-dried at 21 to $23^{\circ} \mathrm{C}$. To discharge ascospores, stem pieces were placed on a $4-\mathrm{cm}^{2}$ bottom dish, which contained WA. Ascospore to $7 \mathrm{~h}$ at 21 to $23^{\circ} \mathrm{C}$ op fertile pseudothecia, two compatible isowith the American Type Culture Collection as testers for mating-type studies with 43 single-spore isolates of A. fabae and 341 single-spore isolates of A. lentis. Additionally, three isolates of each mating type of A. fabae and A. lentis were tested individually and paired in all combinations by the blotter method.

Crosses between A. fabae and A. lentis. Crosses were made between A. fabae isolates AF 1 and AF 4 (Table 1) and $A$. lentis isolates $\mathrm{AL} 1, \mathrm{AL} 2, \mathrm{AL} 3$, and $\mathrm{AL} 84$ (Table 1) in all combinations by the blotter procedure described above. Progeny from these crosses were used in RAPD assays (Table 2). These crosses and those with other isolates of both species were included in morphological and pathogenicity studies. In crosses that produced mature pseudothecia, ascospores were discharged onto WA, and single ascospores were transferred to PDA, FDA, or LDA at 21 to $23^{\circ} \mathrm{C}$ under fluorescent lights (12-h photoperiod).

Pathogenicity tests. The pathogenicity of isolates of A. fabae, A. lentis, and the hybrid progeny from crosses between these two species were tested on faba bean cv. Herz Freya and lentil cv. Spanish Brown (PI 565081, from Spain) in greenhouse inoculation studies. Conidia were collected from PDA, FDA, or LDA by flooding dishes with sterile distilled water and gently scraping the colony surface with a bent glass rod. Conidial suspensions were adjusted to approximately $1 \times 10^{6}$ conidia per $\mathrm{ml}$. The foliage of four to six 10- and 20-day-old plants was sprayed with $15 \mathrm{ml}$ of spore suspension, using an atomizer or airbrush sprayer. Control plants were sprayed with distilled water. Inoculations were repeated once. Inoculated and control plants were incubated in moist chambers for $96 \mathrm{~h}$ and then on a greenhouse bench. Temperatures in the greenhouse ranged from 18 to $22^{\circ} \mathrm{C}$. A completely random design was used to distribute pots both in the moist chamber and on the greenhouse bench. Final disease readings were made 21 days after inoculation, at which time reisolations

\begin{tabular}{cll} 
A. lentis & & \\
21 & AL 1 (96419) & Australia \\
22 & AL 2 (96420) & Brazil \\
23 & AL 3 (46979) & Canada \\
24 & AL 280 & Canada \\
25 & AL 79 & Iran \\
26 & AL 80 & Iran \\
27 & AL 84 (46981) & Spain \\
28 & AL 85 & Spain \\
29 & AL 7 & Syria \\
30 & AL 87 & Syria \\
31 & AL 156 & Syria \\
32 & AL 23 & U.S. \\
33 & AL 70 & U.S. \\
34 & AL 140 & U.S. \\
A. rabiei & & \\
35 & AR 20 (76501) & U.S. \\
36 & AR 21 (76502) & U.S. \\
Unidentified b & & \\
37 & C & Syria \\
38 & A & Lebanon \\
\hline a American Type Culture Collection (Rockville, \\
MD) number. & \\
b Unidentified ascospore isolates from faba bean.
\end{tabular}

Table 2. Isolates of Ascochyta fabae, A. lentis, and their WSU ${ }^{a}$ hybrid progeny used in the random amplified polymorphic DNA assay

\begin{tabular}{lllll}
\hline $\begin{array}{l}\text { Isolate } \\
\text { number }\end{array}$ & Species & $\begin{array}{l}\text { Isolate } \\
\text { designation }\end{array}$ & Mating type & $\begin{array}{l}\text { Country } \\
\text { of origin }\end{array}$ \\
\hline 1 & A. fabae & AF 1 & MAT 1-1 & Canada \\
2 & & WSU 301 & & \\
3 & A. lentis & WSU 302 & MAT 1-2 & Brazil \\
4 & AL 2 & MAT 1-1 & Canada \\
5 & A. fabae & AF 1 & & \\
6 & & WSU 321 & & Spain \\
7 & A. lentis & WSU 322 & MAT 1-2 & Iran \\
8 & A. fabae & AF 4 & MAT 1-2 & \\
9 & & WSU 341 & & Australia \\
10 & A. lentis & WSU 342 & MAT 1-1 & Iran \\
11 & A. fabae & AF 4 & MAT 1-2 & Canada \\
12 & & WSU 361 & & \\
13 & A. lentis & AL 3 & MAT 1-1 & (262 \\
14 & & & & \\
15 & & &
\end{tabular}

${ }^{a}$ Washington State University, Pullman. 
were made from surface-disinfected tissues $(0.25 \% \mathrm{NaOCl}$ for $5 \mathrm{~min})$ placed on WA. The pathogenicity of each isolate to the foliage of faba bean and lentil was based on a disease index of 1 to 5 , in which $1=$ no symptoms, $2=1$ to $10 \%, 3=11$ to $25 \%$, $4=26$ to $50 \%$, and $5=$ necrosis of more than $50 \%$ of the foliage. In disease readings of 2 to 5 , pycnidia usually developed in necrotic tissues. Ascospore isolates A (Lebanon) and C (Syria) from faba bean were inoculated on faba bean, lentil, and chickpea cv. Burpee (PI 458770, from the United States) following the procedure outlined above.

Microscopic techniques and criteria. Ascomata were scraped from tissue on which crosses had been made, crushed in water, and evaluated. Asci were considered abnormal when they contained fewer than eight ascospores. In most cases, 20 randomly selected asci from several ascomata were studied. In some cases, ascomata and/or asci were scarce, and fewer asci were evaluated. At least 10 ascospores floating free of the ascus were measured when possible. In a few cases, ascospores were measured in the ascus when insufficient floating spores were present. Conidia from cultures likewise were measured in water. Mounts were made in phloxine-lactophenol ( $0.5 \mathrm{gm}$ of phloxine, $20 \mathrm{gm}$ of phenol, $20 \mathrm{ml}$ of lactic acid, $40 \mathrm{ml}$

Table 3. Sequences of primers used to amplify DNA for RAPD assays of Ascochyta fabae, A. lentis, and A. rabiei

\begin{tabular}{cl}
\hline Code $^{\mathbf{a}}$ & \multicolumn{1}{c}{$\mathbf{5}^{\prime}$ to $\mathbf{3}^{\prime}$} \\
\hline Set $^{\mathrm{b}} 1$ & \\
B-17 & AGGGAACGAG \\
E-12 & TTATCGCCCC \\
E-14 & TGCGGCTGAG \\
E-16 & GGTGACTGTG \\
K-03 & CCAGCTTAGG \\
K-10 & GTGCAACGTG \\
K-12 & TGGCCCTCAC \\
K-15 & CTCCTGCCAA \\
K-19 & CACAGGCGGA \\
K-20 & GTGTCGCGAG \\
Set 2 & \\
K-01 & CATTCGAGCC \\
K-02 & GTCTCCGCAA \\
K-10 & GTGCAACGTG \\
K-15 & CTCCTGCCAA \\
L-01 & GGCATGACCT \\
L-02 & TGGGCGTCAA \\
L-05 & ACGCAGGCAC \\
L-06 & GAGGGAAGAG \\
L-08 & AGCAGGTGGA \\
L-09 & TGCGAGAGTC \\
L-10 & TGGGAGATGG \\
L-13 & ACCGCCTGCT \\
L-15 & AAGAGAGGGG \\
L-16 & AGGTTGCAGG \\
L-19 & GAGTGGTGAC \\
\hline
\end{tabular}

a Primer designation of Operon Technologies, Alameda, CA.

${ }^{\mathrm{b}}$ Cultures of isolates 1 through 6,9 and 10,12 , 14 and 15,17 and 18, 21 through 33 , and 35 and 36 (Table 1) were analyzed in the first dendrogram (Fig. 4). Cultures of isolates 1 through 20 and 35 and 36 (Table 1) were analyzed in the second dendrogram (Fig. 5).
Table 4. Production of mature pseudothecia by Didymella fabae in crosses among three single-spore isolates of each mating type

\begin{tabular}{|c|c|c|c|c|c|c|c|c|}
\hline \multirow[b]{2}{*}{ Isolate $^{\mathbf{a}}$} & \multirow{2}{*}{$\begin{array}{l}\text { Country } \\
\text { of origin }\end{array}$} & \multirow{2}{*}{$\begin{array}{c}\text { Mating } \\
\text { type }^{\mathrm{b}}\end{array}$} & \multicolumn{6}{|c|}{ Isolate $^{\mathrm{c}}$} \\
\hline & & & AF 1 & AF 8 & AF 19 & AF 3 & AF 4 & AF 18 \\
\hline AF 1 & Canada & 1 & - & - & - & + & + & + \\
\hline AF 8 & U.K. & 1 & & - & - & + & + & + \\
\hline AF 19 & Syria & 1 & & & - & + & + & + \\
\hline AF 3 & Afghanistan & 2 & & & & - & - & - \\
\hline $\mathrm{AF} 4$ & Iran & 2 & & & & & - & - \\
\hline AF 18 & Syria & 2 & & & & & & - \\
\hline
\end{tabular}

${ }^{a}$ Isolates AF 1 and AF 4 (American Type Culture Collection [ATCC] 96418 and ATCC 96409, respectively) were used as testers in these experiments.

${ }^{b}$ Tested previously by crossing with the two testers, AF 1 and AF 4 .

c - indicates pseudothecia did not form; + indicates mature pseudothecia formed.

Table 5. Production of mature pseudothecia by Didymella lentis in crosses among three single-spore isolates of each mating type

\begin{tabular}{|c|c|c|c|c|c|c|c|c|}
\hline \multirow[b]{2}{*}{ Isolate $^{\mathrm{a}}$} & \multirow{2}{*}{$\begin{array}{l}\text { Country } \\
\text { of origin }\end{array}$} & \multirow{2}{*}{$\begin{array}{c}\text { Mating } \\
\text { type }^{\mathrm{b}}\end{array}$} & \multicolumn{6}{|c|}{ Isolate $^{\mathrm{c}}$} \\
\hline & & & AL 1 & AL 3 & AL 23 & AL 2 & AL 84 & AL 143 \\
\hline AL 1 & Australia & 1 & - & - & - & + & + & + \\
\hline AL 3 & Canada & 1 & & - & - & + & + & + \\
\hline AL 23 & U.S. & 1 & & & - & + & + & + \\
\hline AL 2 & Brazil & 2 & & & & - & - & - \\
\hline AL 84 & Spain & 2 & & & & & - & - \\
\hline AL 143 & U.S. & 2 & & & & & & - \\
\hline
\end{tabular}

${ }^{\mathrm{a}}$ Isolates AL 1 and AL 2 (American Type Culture Collection [ATCC] 96419 and ATCC 96420, respectively) were used as testers in the pairing experiments.

b Tested previously by crossing with the two testers, AL 1 and AL 2 .

c - indicates pseudothecia did not form; + indicates mature pseudothecia formed.

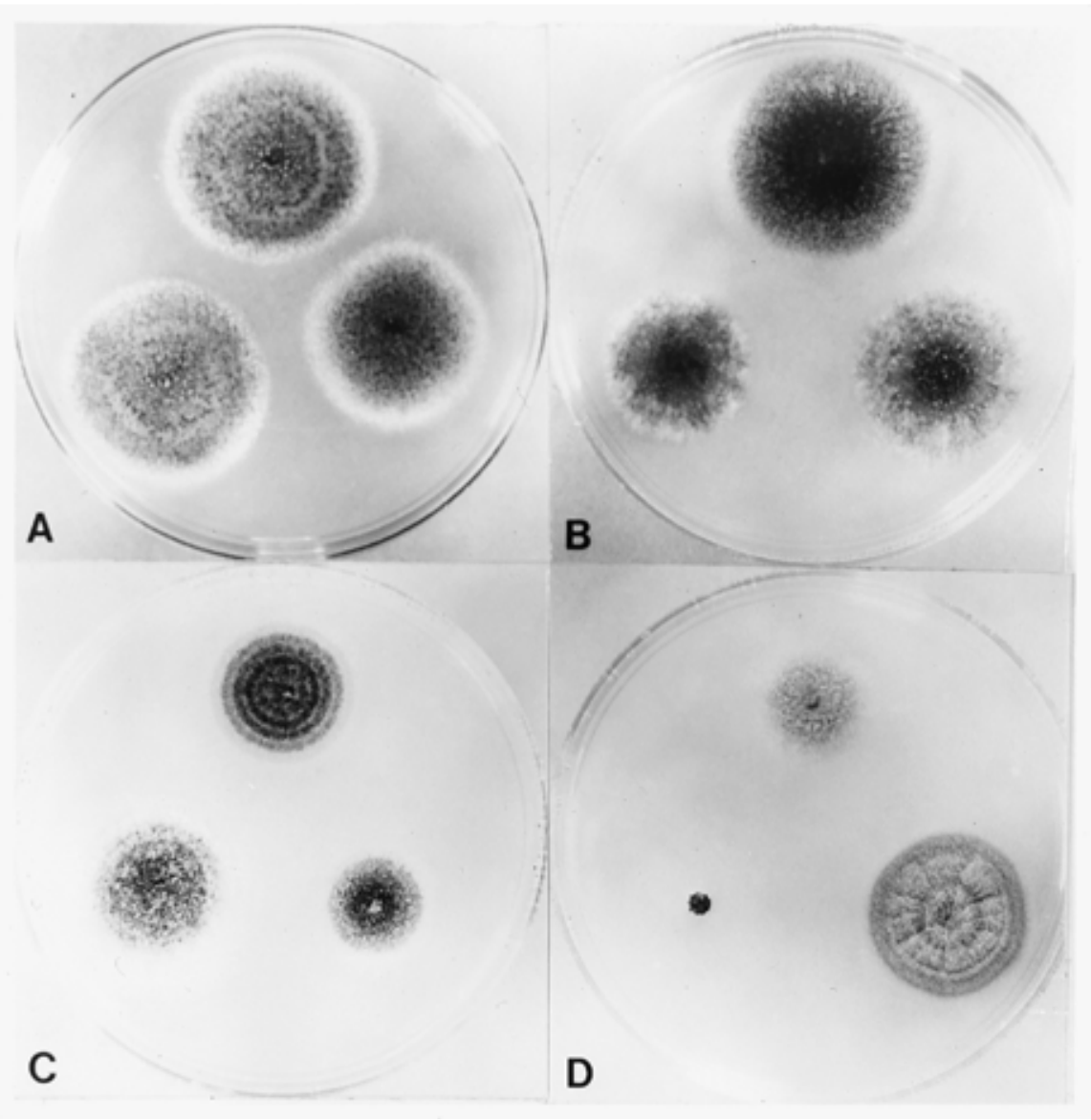

Fig. 1. Differences in growth, sporulation, and colony appearance of 9-day-old single-ascospore cultures on potato dextrose agar of crosses between isolates of Ascochyta fabae American Type Culture Collection (ATCC) 96418 and ATCC 96409 and A. lentis ATCC 96419 and ATCC 96420 and crosses between the two species. (A) Cross between isolates of $A$. fabae; (B) cross between isolates of $A$. lentis; (C) cross between A. fabae ATCC 96418 and A. lentis ATCC 96420; and (D) cross between A. fabae ATCC 96409 and A. lentis ATCC 96419. 
of glycerin, and $20 \mathrm{ml}$ of distilled water) to better observe septation and ascus morphology.

Total DNA extraction. Single-spore cultures were grown on PDA. Subsequently, they were subcultured in test tubes containing PDA with $5 \mathrm{~g}$ of yeast extract per liter and maintained at $4{ }^{\circ} \mathrm{C}$. The cultures were transferred to $40 \mathrm{ml}$ of Difco yeast and malt extract broth and grown at room temperature for 10 days. The mycelial mat was lyophilized for approximately $48 \mathrm{~h}$, mixed with sterile sand, and ground into fine powder with a mortar and pestle. DNA was extracted from $25 \mathrm{mg}$ of freeze-dried mycelial powder by a minipreparation protocol modified from the cetyltrimethylammonium bromide procedure described by Weising et al. (17).

The DNA pellet was resuspended in $100 \mu \mathrm{l}$ of TE buffer $(10 \mathrm{mM}$ Tris- $\mathrm{HCl}$ and $1 \mathrm{mM}$ EDTA, $\mathrm{pH}$ 8.0), and this was quantified by the minigel method (14). DNA concentration was estimated by comparison of the ethidium bromide stain intensity with that of standard $\lambda$-HindIII DNA (Gibco BRL, Bethesda, MD). DNA was diluted to a $1 \mathrm{ng} / \mu \mathrm{l}$ concentration and used in polymerase chain reaction (PCR).

PCR. Each amplification reaction was performed in a $12.5-\mu$ l volume consisting of $1.25 \mu \mathrm{l}$ of $10 \times \mathrm{Taq}$ polymerase buffer (Promega, Madison, WI); $0.2 \mathrm{mM}$ each of dATP, dCTP, dGTP, and dTTP (Sigma Chemical Co., St. Louis); $0.32 \mu \mathrm{M}$ random primer; $4 \mathrm{mM} \mathrm{MgCl}_{2} ; 0.3$ units of Taq DNA

Table 6. The pathogenicity of isolates of Ascochyta fabae and A. lentis, crosses between the two species to faba bean and lentil, and the morphology of the asci and ascospores resulting from these crosses

\begin{tabular}{|c|c|c|c|c|c|c|}
\hline \multirow[b]{2}{*}{ Species } & \multirow[b]{2}{*}{ Isolate } & \multirow{2}{*}{$\begin{array}{l}\text { Country } \\
\text { of origin }\end{array}$} & \multicolumn{2}{|c|}{ Pathogenicity ${ }^{\mathbf{a}}$} & \multicolumn{2}{|r|}{ Morphological characteristics } \\
\hline & & & Faba bean & Lentil & Asci & Ascospores $(\mu \mathrm{m})$ \\
\hline A. fabae & $\mathrm{AF} 1$ & Canada & 3 & 1 & & \\
\hline A. fabae & AF 2 & Canada & 3 & 1 & & \\
\hline A. fabae & AF 3 & Afghanistan & 2 & 1 & & \\
\hline A. fabae & $\mathrm{AF} 4$ & Iran & 4 & 1 & & \\
\hline A. fabae & $\mathrm{AF} 8$ & U.K. & 3 & 1 & & \\
\hline A. fabae & AF 9 & U.K. & 3 & 1 & & \\
\hline A. fabae & AF 13 & Canada & 2 & 1 & & \\
\hline A. fabae & AF 16 & Spain & 3 & 1 & & \\
\hline A. fabae & AF 18 & Syria & 3 & 1 & & \\
\hline A. fabae & AF 19 & Syria & 3 & 1 & & \\
\hline A. lentis & AL 1 & Australia & 1 & 3 & & \\
\hline A. lentis & AL 2 & Brazil & 1 & 3 & & \\
\hline A. lentis & AL 3 & Canada & 1 & 2 & & \\
\hline A. lentis & AL 84 & Spain & 1 & 2 & & \\
\hline A. lentis & AL 143 & U.S. & 1 & 3 & & \\
\hline \multicolumn{7}{|l|}{ Cross $^{\mathrm{b}}$} \\
\hline \multicolumn{7}{|l|}{ A. fabae $\times$ A. fabae } \\
\hline & $\mathrm{AF} 1 \times \mathrm{AF} 3$ & & 3 & 1 & $\mathrm{~N}^{\mathrm{c}}$ & (17.6) $20.6-23.5 \times 7.3-9.5(-11.8)$ \\
\hline & $\mathrm{AF} 1 \times \mathrm{AF} 4$ & & 3 & 1 & $\mathrm{~N}$ & $16-22 \times 8-9.5$ \\
\hline & $\mathrm{AF} 1 \times \mathrm{AF} 9$ & & 2 & 1 & $\mathrm{~N}$ & $(17-) 17.6-20.6 \times(6.6-) 7.3-8.8$ \\
\hline & $\mathrm{AF} 1 \times \mathrm{AF} 18$ & & 2 & 1 & $\mathrm{~N}$ & $14.7-17.6(-18.4) \times 6.6-7.3(-8)$ \\
\hline & $\mathrm{AF} 2 \times \mathrm{AF} 8$ & & 2 & 1 & $\mathrm{~N}$ & $14.7-17.6 \times 5.9$ \\
\hline & $\mathrm{AF} 2 \times \mathrm{AF} 19$ & & 3 & 1 & $\mathrm{~N}$ & $14.7-17.6 \times 6.6-7.3$ \\
\hline & $\mathrm{AF} 4 \times \mathrm{AF} 13$ & & 2 & 1 & $\mathrm{~N}$ & $17.6-22 \times 7.3-8.8$ \\
\hline & $\mathrm{AF} 4 \times \mathrm{AF} 16$ & & 2 & 1 & $\mathrm{AN}^{\mathrm{d}}(8 / 12)$ & $16-20.6(22) \times(7.3) 8-9.5(10.3)$ \\
\hline & $\mathrm{AF} 8 \times \mathrm{AF} 9$ & & 3 & 1 & $\mathrm{~N}$ & $16-17.6(20.9) \times 5.9-7.3$ \\
\hline & $\mathrm{AF} 8 \times \mathrm{AF} 18$ & & 2 & 1 & AN (7/6) & $17.6-22 \times 7.3-8.8(10.3)$ \\
\hline & $\mathrm{AF} 9 \times \mathrm{AF} 19$ & & 2 & 1 & AN (7/13) & $14.7-16 \times 6.6-7.3$ \\
\hline & AF $18 \times$ AF 19 & & 2 & 1 & AN $(2 / 2)$ & $14.7-16 \times(4.4) 6.6-7.3$ \\
\hline \multicolumn{7}{|l|}{ A. lentis $\times$ A. lentis } \\
\hline & $\mathrm{AL} 1 \times \mathrm{AL} 2$ & & 1 & 3 & $\mathrm{~N}$ & (11.8) $14.7-17.6 \times 5.9-7.3$ \\
\hline & $\mathrm{AL} 1 \times \mathrm{AL} 84$ & & 1 & 3 & & \\
\hline & $\mathrm{AL} 1 \times \mathrm{AL} 143$ & & 1 & 2 & $\mathrm{~N}$ & $14.7-17.6 \times 6.6-7.3(-10.3)$ \\
\hline & $\mathrm{AL} 2 \times \mathrm{AL} 3$ & & 1 & 2 & & \\
\hline & AL $3 \times$ AL 84 & & 1 & 2 & $\mathrm{~N}$ & (11.8) $14.7-17.6 \times 5-6.6$ \\
\hline \multicolumn{7}{|l|}{ A. fabae $\times$ A. lentis } \\
\hline & $\mathrm{AF} 1 \times \mathrm{AL} 2$ & & 1 & 1 & AN (18/2) & $14.7-19 \times 5.9-8.8$ \\
\hline & $\mathrm{AF} 1 \times \mathrm{AL} 84$ & & 1 & 1 & AN $(16 / 0)$ & $\begin{array}{l}16-17.6 \times 7.3 \text { (spores single in ascus, } \\
20-22 \times 8.8)\end{array}$ \\
\hline & $\mathrm{AF} 4 \times \mathrm{AL} 1$ & & 1 & 1 & & \\
\hline & $\mathrm{AF} 4 \times \mathrm{AL} 3$ & & 1 & 1 & & \\
\hline & $\mathrm{AF} 8 \times \mathrm{AL} 2$ & & 1 & 1 & AN (20/0) & $13.3-17 \times 5.9-7.3(-8)$ \\
\hline & $\mathrm{AF} 9 \times \mathrm{AL} 1$ & & 1 & 1 & AN $(20 / 0)$ & $13.7-17.6 \times 5.9-7.3(9.5)$ \\
\hline \multicolumn{7}{|l|}{ Teleomorph } \\
\hline D. fabae U.K.-field & & & & & $\mathrm{N}$ & $(14.7) 17.6-18.4(-19) \times 7.3-8.8(9.5)$ \\
\hline D. fabae U.K.-field isotype & & & & & & $14.7-16 \times 5.9-8$ \\
\hline D. fabae U.K.-type description & & & & & & $15-18 \times 5.5-6.5$ \\
\hline
\end{tabular}

${ }^{a}$ Faba bean cv. Herz Freya and lentil cv. Spanish Brown were used in the pathogenicity studies. The pathogenicity of each isolate to the foliage of test plants was based on a disease index scale of 1 to 5 , in which $1=$ no symptoms; $2=1$ to $10 \% ; 3=11$ to $25 \% ; 4=26$ to $50 \%$; and $5=$ more than $50 \%$ necrosis of the foliage.

${ }^{\mathrm{b}}$ Two to eight single-ascospore progeny from each of the crosses between isolates of A. fabae, A. lentis, and A. fabae and A. lentis were tested for pathogenicity on faba bean and lentil.

${ }^{c} \mathrm{~N}=$ normal asci. Twenty asci usually were assessed at random. In some cases, fewer than 20 asci were observed. At least 10 ascospores floating free of the ascus were measured when possible.

${ }^{\mathrm{d}} \mathrm{AN}=$ abnormal asci. Numbers in parenthesis indicate the number of abnormal asci per the number of normal asci. 
polymerase (Promega); and 1 ng of DNA template. Sterile distilled water was used in place of DNA template as a control to ensure there was no contamination. The solution was overlaid with mineral oil. For amplification of DNA, different sets of 10 and 15 primers were used in the two parts of the RAPD analysis, respectively (Table 3). Amplification was carried out in a PerkinElmer (Norwalk, CT) model 480 thermal cycler programmed as follows: step $1,94^{\circ} \mathrm{C}$ for $5 \mathrm{~min}$; step 2,45 cycles of $94^{\circ} \mathrm{C}$ for 1 min, $36^{\circ} \mathrm{C}$ for $1 \mathrm{~min}$, and $72^{\circ} \mathrm{C}$ for $2 \mathrm{~min}$; and step $3,72^{\circ} \mathrm{C}$ for $7 \mathrm{~min}$. After amplification, $4 \mu \mathrm{l}$ of the solution of each sample was electrophoresed in $1.5 \%$ gel that was half low-melting and half ultrapure agarose in $0.5 \times$ TBE buffer $(0.089 \mathrm{M}$ Tris-borate, $0.089 \mathrm{M}$ boric acid, and 0.002 M EDTA). The gel was stained with ethidium bromide and photographed under UV light.

Data analysis. Using the Numerical Taxonomy and Multivariate Analysis System (NTSYS-pc), version 1.80 (13), a matrix for each data set was constructed by scoring for the presence (1) or absence (0) of RAPD bands. A similarity matrix, using Dice's coefficient, was constructed in the SIMQUAL program. The dendrogram was generated by the unweighted pair-group method with arithmetic average in the SAHN program and constructed by the TREE program. Bootstrapping support for the branches of the dendrogram was obtained by 1,000 replications in the WINBOOT program (11).

\section{RESULTS}

Mating type. Pseudothecia of $D$. fabae and $D$. lentis were never observed in blight lesions that developed on the foliage of living plants in the greenhouse inoculation studies. Pseudothecia developed on lentil stem pieces inoculated with some mixtures of single-ascospore or conidial isolates of A. fabae and A. lentis, but they did not develop on tissue inoculated with isolates of these fungi obtained from a single ascospore or conidium or with other mixtures of certain single-spore isolates.

All 43 single-spore isolates of $A$. fabae tested by the blotter method were self-sterile, as were 341 single-spore isolates of $A$. lentis, and only pycnidia developed on inoculated lentil stem pieces. With testers ATCC 96418 and ATCC 96409, 26 and 17 isolates of $A$. fabae produced pseudothecia, respectively, whereas with testers ATCC 96419 and ATCC 96420156 and 185 isolates of A. lentis produced pseudothecia, respectively. All isolates were self-sterile, and all were fertile when mated with a compatible tester.

When three selected isolates of each group (mating type) were paired in all possible combinations and were inoculated alone, pseudothecia formation on lentil straw confirmed the previous division into two compatibility groups or mating types, designated MAT1-1 and MAT1-2 as proposed by Yoder et al. (19) (Tables 4 and 5). These
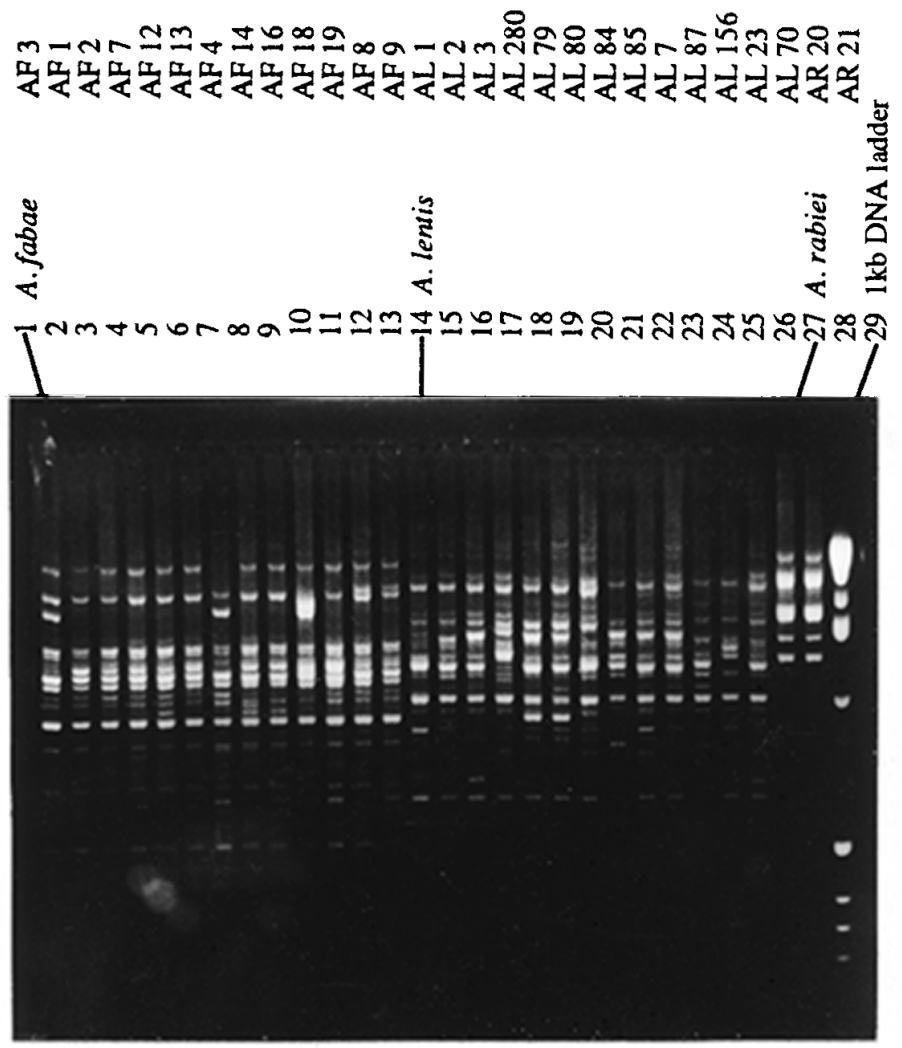

Fig. 2. Random amplified DNA polymorphisms of Ascochyta fabae (lanes 1 through 13), A. lentis (lanes 14 through 26), and A. rabiei (lanes 27 and 28) with primer K-20.
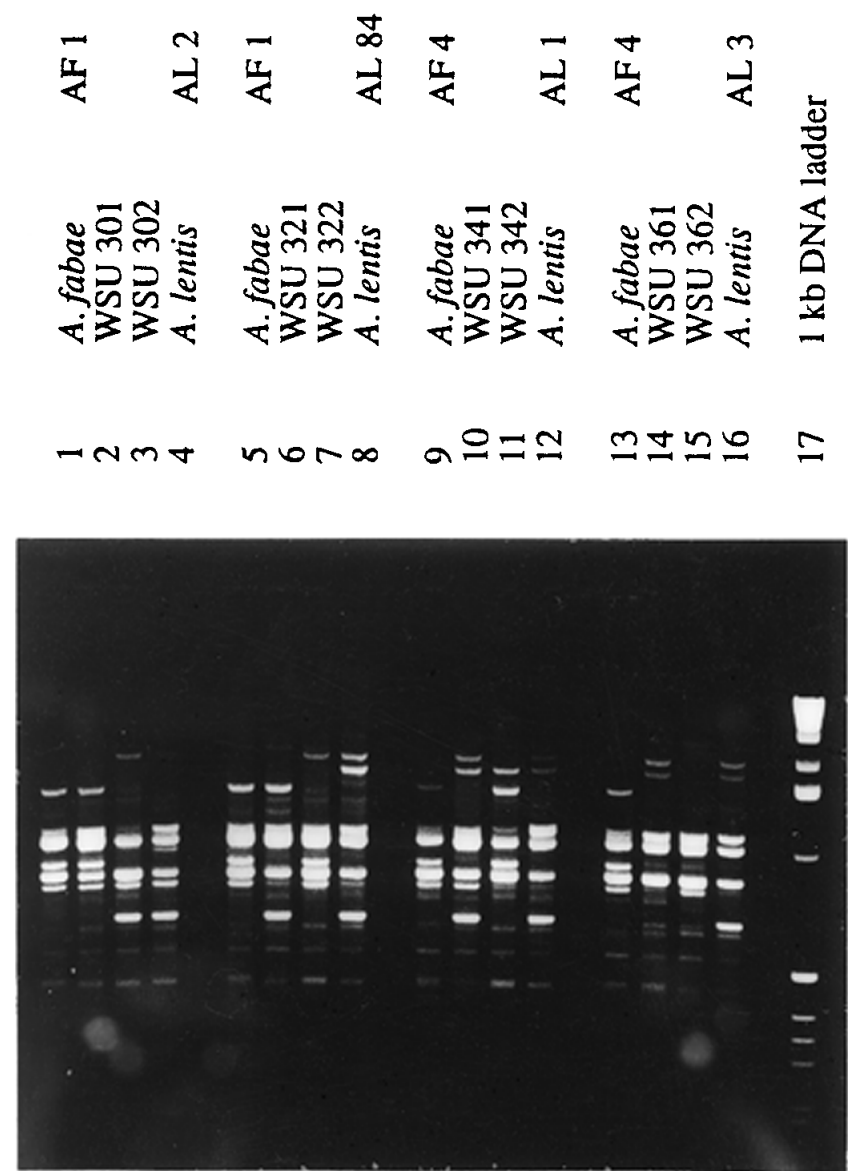

Fig. 3. Random amplified DNA polymorphisms of Ascochyta fabae, A. lentis, and their hybrid progeny generated with primer L- 05 . 
mating studies confirm that both fungi are heterothallic and bipolar. Sexual reproduction only occurred in crosses between isolates of the opposite mating type. No teleomorph developed when $D$. rabiei MAT 1-1 and MAT1-2 isolates were paired with either mating type of $A$. fabae or A. lentis.

Pathogenicity studies. A. fabae isolates inoculated to faba bean and lentil caused disease only on faba bean (Table 6). Conversely, $A$. lentis isolates inoculated to faba bean and lentil incited disease only on lentil. Moreover, single-ascospore isolates defaba bean, whereas single-ascospore isolates from $D$. lentis incited disease only on lentil (Table 6). Progeny derived from single ascospores from hybrid pseudothecia oblentis isolates did not cause disease on either faba bean or lentil (Table 6). Two to eight hybrid progeny from each of the six crosses between isolates of $A$. fabae and $A$. lentis were tested for pathogenicity. Pycnidia usually developed in necrotic lesions on the foliage of faba bean inoculated with isolates of $A$. fabae and on lentil inoculated with isolates of $A$. lentis. These fungi were reisolated from surface-disinfected necrotic rived from $D$. fabae caused disease only on tained by crossing $A$. fabae isolates with $A$.

tissues placed on WA. Occasionally, a few small reddish flecks $(<2 \mathrm{~mm}$ in diameter) were observed on lentil inoculated with $A$. fabae or faba bean inoculated with A. lentis. Similar reddish spots developed infrequently on faba bean or lentil when inoculated with hybrid progeny of crosses between the two fungi. The lesions did not increase in size, and the isolates did not sporulate in the lesions. Hybrid isolates were recovered from $<25 \%$ of the surface-disinfected tissues. Ascospore isolates A (Lebanon) and C (Syria) from faba bean differed in their pathogenicity to chickpea and faba bean. Isolate $\mathrm{A}$ infected chickpea but not faba bean or lentil, whereas, isolate $\mathrm{C}$ infected faba bean but not chickpea or lentil. Symptoms of isolate A on chickpea were indistinguishable from those induced by isolates of $A$. rabiei (W. J. Kaiser, unpublished data), whereas symptoms of isolate $\mathrm{C}$ on faba bean were identical to those caused by isolates of A. fabae (Table 6).

Morphological characteristics. Growth, sporulation, colony appearance, and morphology of single-ascospore progeny from crosses between $A$. fabae and A. lentis frequently varied greatly from either parent (Fig. 1). Asci of four of the A. fabae and A.

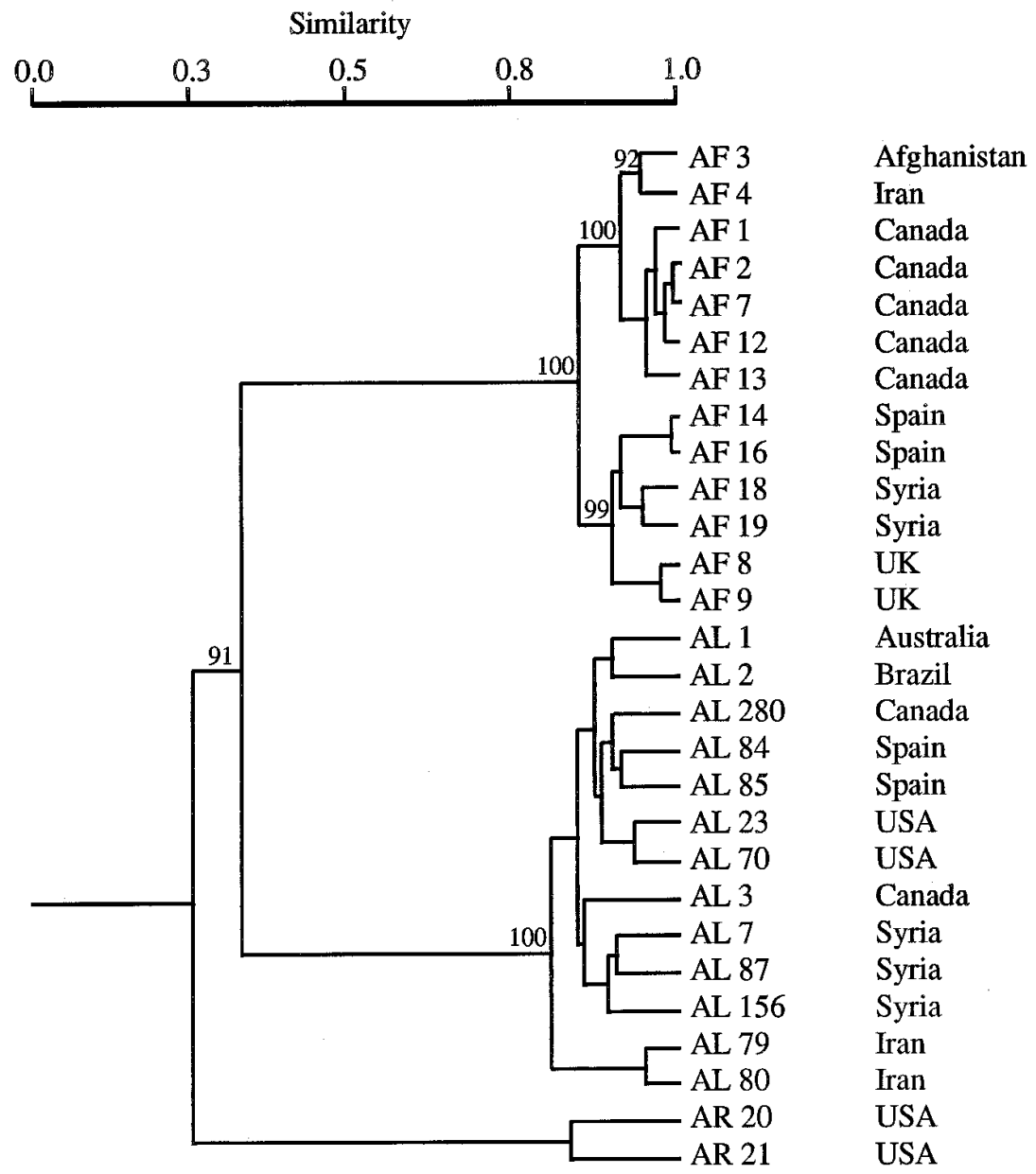

Fig. 4. Dendrogram of random amplified polymorphic DNA (RAPD) of Ascochyta fabae and A. lentis. The numbers at the forks show the bootstrap percentage of times the group occurred. Set 1 primers (Table 3) were used for the RAPD assays. lentis crosses examined were mostly abnormal, having fewer than eight ascospores that on average were larger than those from eight-spored asci (Table 6). Asci and ascospores from pseudothecia from crosses among isolates of A. lentis appeared normal and were similar in size to the type description of D. fabae (6). Ascospores obtained from pseudothecia from crosses between $A$. fabae isolates fell into two general size classes. One class is close to the range given in the type description of $D$. fabae, 15 to $18 \times 5.5$ to $6.5 \mu \mathrm{m}$ (6). This class includes crosses between U.K. isolates AF 8 and AF 9; U.K. AF 9 and Syria AF 19; U.K. AF 8 and Canada AF 2; Syria AF 19 and Canada AF 2; and Syria AF 18 and Canada AF 1. The other class has an ascospore size range that is larger than that reported in the type description, including the isolates Spain AF 16 and Iran AF 4; U.K. AF 8 and AF 9, Syria AF 18, and Canada AF 1; Canada AF 13 and Iran AF 4; Canada AF 1 and Afghanistan AF 3; Canada AF 1 and Iran AF 4; and U.K. AF 8 and AF 9. Four of the crosses showed abnormal asci, chiefly asci with fewer than eight ascospores (Table 6), indicating that within $D$. fabae a partial reproductive imbalance exists among some isolates. Singleascospore progeny from the four A. fabae crosses with abnormal asci or progeny from crosses producing ascospores larger than is typical for $D$. fabae infected faba bean and caused symptoms identical to those induced by progeny from other $A$. fabae crosses used in this study (Table 6).

RAPD assays. The RAPD banding patterns of isolates of A. fabae clearly were different from those of A. lentis (Fig. 2). The RAPD banding patterns from hybrid progeny from crosses between $A$. fabae and A. lentis confirmed hybridity (Fig. 3 ). The RAPD dendrogram presented in Figure 4 depicts distinct $A$. fabae and $A$. lentis clusters, with the outgroup, A. rabiei, forming a third, distantly related cluster. Examination of the A. fabae cluster reveals differences among isolates. The RAPD dendrogram of isolates of A. fabae shows that the isolates cluster essentially according to their geographic origin (Fig. 5). There are two major clusters: one group includes isolates from Afghanistan, Canada, Germany, and Iran; another group includes isolates from Syria and the United Kingdom. Within the first group, one German A. fabae isolate subclustered with isolates from Afghanis$\tan$ and Iran, whereas the other German isolate subclustered with isolates from Canada (Fig. 5). All RAPD assays were done twice, and only the reproducible bands were scored.

Unidentified ascospore isolate $\mathrm{C}$ from Syria had RAPD profiles, generated with primers K-08 and K-17, similar to known A. fabae isolates (Fig. 6). However, Lebanon isolate A had profiles similar to known A. rabiei isolates. The other RAPD profiles generated with primers B-17, K-10, K-19, and K-20 had the same results. 


\section{DISCUSSION}

Based on several types of data, we accept $A$. fabae and A. lentis as distinct species. First, conidial isolates from faba bean did not cause disease of lentil, and isolates from lentil did not cause disease of faba bean. Second, compatible isolates from faba bean and lentil when mated with isolates from the same host produced Didymella teleomorphic states. Ascospore progeny from matings between faba bean isolates induced disease only on faba bean; ascospore progeny from matings between lentil isolates induced disease only on lentil. Hybrid ascospore progeny from crosses between faba bean and lentil isolates did not cause disease on either faba bean or lentil (Table 6). Moreover, 90 to $100 \%$ of the asci formed in these crosses were abnormal. This leads us to conclude that the isolates from faba bean and lentil represent distinct taxa. The fact that hybrid pseudothecia can form between faba bean and lentil isolates indicates a common origin or progenitor for these taxa, but the failure of hybrid ascospores to incite disease in either faba bean or lentil and the high number of abnormal asci indicate strongly that speciation has occurred. Moreover, RAPD banding patterns of isolates from faba bean and lentil are clearly different, and banding patterns from ascospores from hybrid pseudothecia are hybrid. The results of dendrogram analysis show they have low similarity (Fig. 4). We, thus, accept $D$. fabae, with its anamorph $A$. fabae, as a species. We propose D. lentis, with its anamorph $A$. lentis, as a new species. We agree with Gossen et al. (2) that these taxa are indistinguishable morphologically. However, our data indicate that we are dealing with biological species rather than formae speciales.

During the last 20 to 25 years, there has been a steady increase in the exchange of germ plasm of cool-season food legumes between countries (8). Seed transmission has been responsible for the introduction of the Ascochyta blight pathogen of faba bean into and within many countries worldwide (8). A. fabae has been introduced into several countries on seed used for crop improvement and commercial purposes. Singleconidium isolates of $A$. fabae from seed of faba bean cultivars obtained from various regions of the world were classified into 10 groups based on morphological characteristics in culture (10). Recently, resistance was found within a germ plasm collection of faba bean lines, and eight isolates of $A$. fabae were classified into four races (4). Likewise, 8 inbred lines differentiated 10 isolates of $A$. fabae into 7 races (12). In the current study, molecular data (Figs. 4 and 5) show that $A$. fabae isolates can be subgrouped according to geographic distribution, except for two isolates from Germany. This pathogen might have originated in the Afghanistan-Iran region. Chickpea, faba bean, and lentil are believed to have originated in the Fertile Crescent of the Near East (15).
From their center of origin, these crops and their associated Ascochyta pathogens have been transported to many countries (8). The presence of a sexual state may represent a source of genetic variability. New locally virulent forms of $A$. fabae may emerge (or have emerged) via selection by plant cultivars and environmental factors.

A highly interesting finding that emerged from matings between certain $A$. fabae isolates was the production of pseudothecia with ascospores considerably larger than is typical for D. fabae. Crosses involving isolates from Iran, Canada, Syria, Afghanistan, the United Kingdom, and Spain gave rise to large-spored forms. A cross between the two Syrian isolates yielded ascospores in the normal size range. The behavior of the Syrian isolates in crosses puzzles us, and we cannot speculate about its status at this time. In any case, either a large-spored variant of $D$. fabae or an undescribed pathogen of faba bean has been discovered. We do not formally describe it here, but it possibly could be used to track the introduction of the pathogen into Iran, Canada, and Spain. Large-spored isolates of A. fabae were compatible with small-spored isolates and produced single-ascospore progeny pathogenic to faba bean.

Ascochyta blight of chickpea caused by A. rabiei is important in eastern Washington and northern Idaho (7). Results of the RAPD assay indicate that the unidentified ascospore isolate from faba bean from Lebanon (A) had a banding pattern similar or

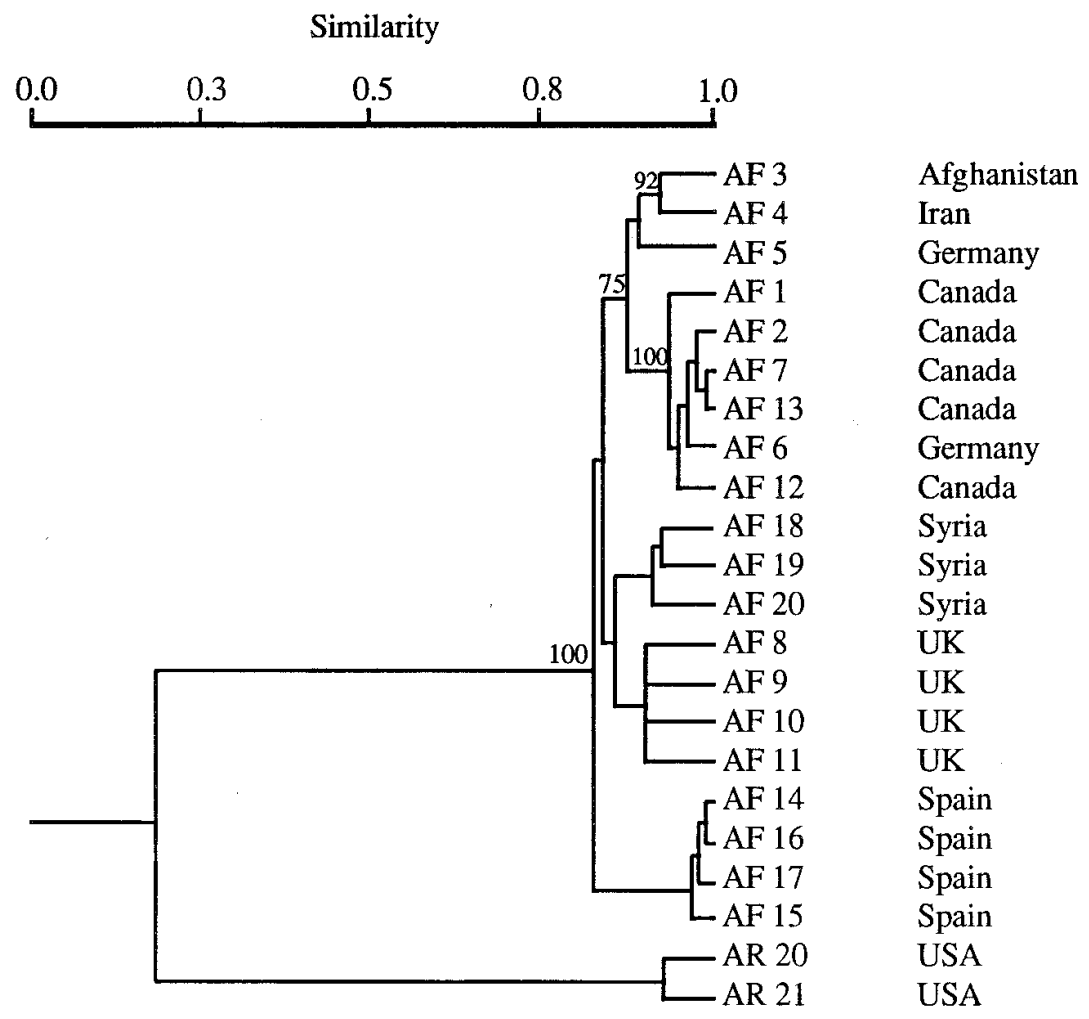

Fig. 5. Dendrogram of random amplified polymorphic DNA (RAPD) of isolates of Ascochyta fabae. The numbers at the forks show the bootstrap percentage of times the group occurred. Set 2 primers (Table 3) were used for the RAPD assays. almost identical to that of known A. rabiei isolates (Fig. 6). Isolate A from Lebanon also was compatible with $A$. rabiei tester isolate AR 21 (ATCC 76502) and produced fertile pseudothecia. Therefore, it is considered to be $A$. rabiei. The host range of A. rabiei includes 11 plant species, including lentil (7). Faba bean seems to be a new host of A. rabiei. Lesions typical of $A$. rabiei developed on chickpea inoculated with isolate A, whereas on faba bean isolate C (Syria) induced symptoms identical to those caused by $A$. fabae. In a separate study, the identity of two ascospore isolates from pea (Pisum sativum) and lentil from Pullman, WA, was confirmed as A. rabiei by RAPD markers, pathogenicity tests, and crossing studies.

\section{LATIN DESCRIPTION}

Didymella lentis Kaiser, B.-C. Wang, \& J.D. Rogers. A Didymella fabae differt in hospite generis Lentis. Differs from $D$. fabae in the host genus Lens (6). Ascomata on leaves or pods solitary to gregarious, 150 to $250 \mu \mathrm{m}$ diameter, subglobose with short to obsolete ostiolar beak. Asci bitunicate, short-stipitate subcylindric to clavate, eight-spored, 59 to $95 \times 10.5$ to $12 \mu \mathrm{m}$. Ascospores hyaline to yellowish in ascus, becoming brown when released, twocelled, biconic to inequilateral (slippershaped), constricted at septum, (11.8-) 14.7 to $17.6 \cdot(5.9-) 6.6$ to $8(-8.8) \mu \mathrm{m}$, one cell broadly rounded, the other less broadly rounded to somewhat acute. Hamathecial 

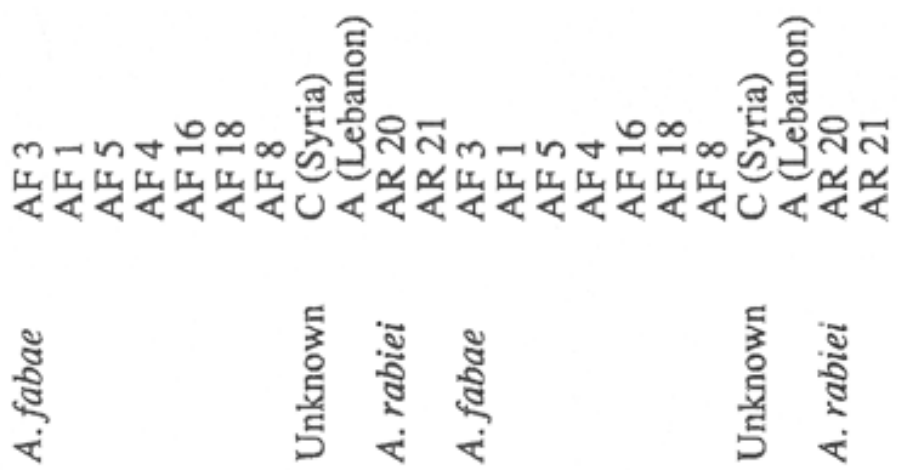

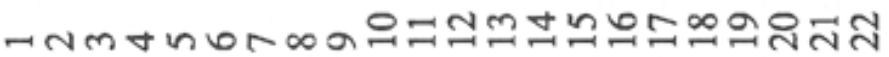

\section{K-08}

\section{$\mathrm{K}-17$}

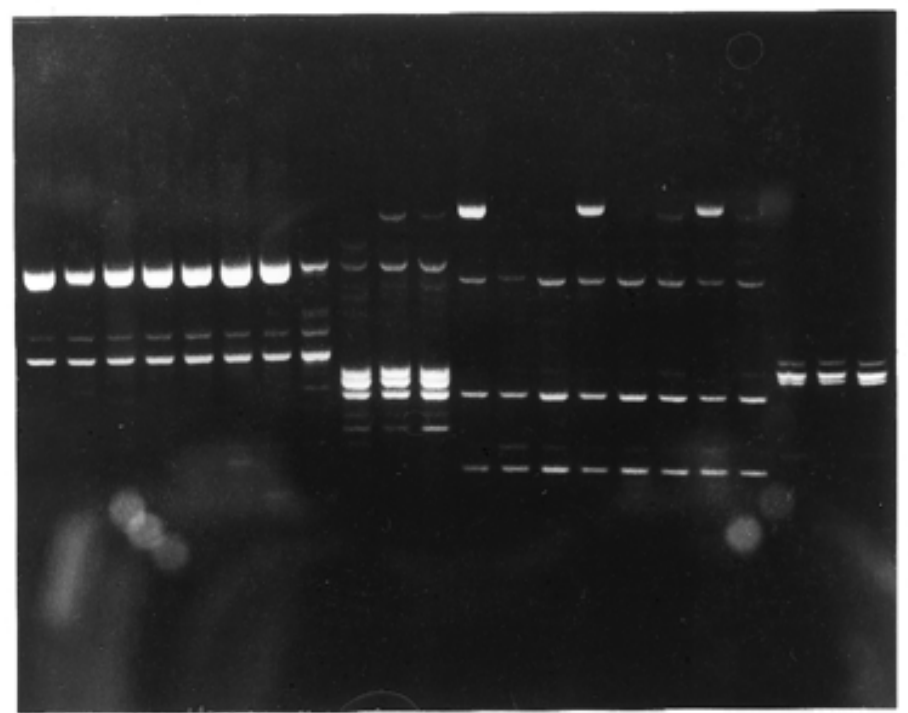

Fig. 6. Random amplified polymorphic DNA markers of unidentified taxa (lanes 8 and 9 and 19 and 20), Ascochyta fabae (lanes 1 through 7 and 12 through 18), and A. rabiei (lanes 10 and 11 and 21 and 22) generated with primers K-08 and K-17.

elements (? pseudoparaphyses) narrow, not abundant in mature ascomata. Anamorph: Ascochyta lentis Vassilievsky.

HOLOTYPE: Pseudothecia from a cross between isolate ATCC 96419 (MAT1-1) (Australia) and isolate ATCC 96420 (MAT12) (Brazil) on stem pieces of lentil (Lens culinaris Medik.) (WSP 69683).

\section{ACKNOWLEDGMENTS}

We thank the cooperators in 16 countries who supplied W. J. Kaiser with isolates of Ascochyta fabae and A. lentis; G. W. Bruehl for valuable and stimulating discussions during the course of these studies; B. C. Hellier for competent technical assistance;. M. J. Adams for aid with photography; and L. M. Carris, D. A. Johnson, and T. D. Murray for presubmission reviews.

\section{LITERATURE CITED}

1. Bondartzeva-Monteverde, V. N., and Vassilievsky, N. I. 1938. A contribution to the biology and morphology of some species of Ascochyta on Leguminosae. Acta Inst. Bot. Acad. Sci. URSS, 1938, Ser. 2 (Pl. Crypt.):345-376.
In Russian.

2. Gossen, B. D., Sheard, J. W., Beauchamp, C. J., and, Morrall, R. A. A. 1986. Ascochyta lentis renamed Ascochyta fabae f. sp. lentis. Can. J. Plant Pathol. 8:154-160.

3. Gossen, B. D., Sheard, J. W., and Morrall, R. A. A. 1984. Multivariate comparisons of morphological and cultural characteristics of Ascochyta lentis and Ascochyta fabae. (Abstr.) Can. J. Plant Pathol. 6:262.

4. Hanounik, S. B., and Robertson, L. D. 1989 Resistance in Vicia faba germ plasm to blight caused by Ascochyta fabae. Plant Dis. 73:202205.

5. Hansen, H. N., and Snyder, W. C. 1947. Gaseous sterilization of biological materials for use as culture media. Phytopathology 37:369371.

6. Jellis, G. J., and Punithalingam, E. 1991. Discovery of Didymella fabae sp. nov., the teleomorph of Ascochyta fabae, on faba bean straw. Plant Pathol. 40:150-157.

7. Kaiser, W. J. 1990. Host range of the Ascochyta blight pathogen of chickpea. (Abstr.) Phytopathology 80:889-890.

8. Kaiser, W. J. Inter- and intranational spread of Ascochyta pathogens of chickpea, faba bean, and lentil. Can. J. Plant Pathol. In press.

9. Kaiser, W. J., and Hellier, B. C. 1993. Didymella sp., the teleomorph of Ascochyta fabae f. sp. lentis, on lentil straw. (Abstr.) Phytopathology 83:692.

10. Kharbanda, P. D., and Bernier, C. C. 1980. Cultural and pathogenic variability among isolates of Ascochyta fabae. Can. J. Plant Pathol. 2:139142.

11. Nelson, R. J., Baraoidan, M. R., Vera Cruz, C. M., Yap, I. V., Leach, J. E., Mew, T. W., and Leung, H. 1994. Relationship between phylogeny and pathotype for the bacterial blight pathogen of rice. Appl. Environ. Microbiol. 60:3275-3283.

12. Rashid, K. Y., Bernier, C. C., and Conner, R. L. 1991. Evaluation of fava bean for resistance to Ascochyta fabae and development of host differentials for race identification. Plant Dis. 75:852-855.

13. Rohlf, F. J. 1993. NTSYS-pc: Numerical Taxonomy and Multivariate Analysis System. Version 1.80. Exeter Software, Setauket, NY.

14. Sambrook, J., Fritsch, E. F., and Maniatis, T 1989. Molecular Cloning: A Laboratory Manual 2nd ed. Cold Spring Harbor Laboratory Press, Cold Spring Harbor, NY.

15. Smartt, J. 1984. Evolution of grain legumes. I Mediterranean pulses. Exp. Agric. 20:275296.

16. Trapero-Casas, A., and Kaiser, W. J. 1992 Development of Didymella rabiei, the teleomorph of Ascochyta rabiei, on chickpea straw. Phytopathology 82:1261-1266.

17. Weising, K., Nybom, H., Wolff, K., and Meyer, W. 1995. DNA Fingerprinting in Plants and Fungi. 1st ed. CRC Press, Ann Arbor, MI

18. Wilson, A. D., and Kaiser, W. J. 1995. Cytology and genetics of sexual incompatibility in Didymella rabiei. Mycologia 87:795804.

19. Yoder, O. C., Valent, B., and Chumley, F 1986. Genetic nomenclature and practice for plant pathogenic fungi. Phytopathology 76:383-385. 